\author{
D.D.Yessimkhanov', Zh.S.Begimbayeva ${ }^{2}$ \\ ${ }^{1}$ Master's degrees student $2^{\text {nd }}$ course Aktobe regional university named after K.Zhubanov, \\ Aktobe, Kazakhstan, E-mail: good_treiser.97@mail.ru \\ ${ }^{2}$ c.h.s., associate professor of the Aktobe regional university named after K.Zhubanov, Aktobe, \\ Kazakhstan, E-mail:shibek_07@mail.ru
}

\title{
PROCEEDINGS OF THE «SOCIETY FOR THE STUDY OF THE KAZAKH REGION» AS A SOURCE FOR RESEARCH HISTORY AND GEOGRAPHY OF KAZAKHSTAN
}

\section{Annotation}

This article is devoted to the study of the "Works» of the Society for the study of the Kazakh region. The «Society for the study of the Kazakh region» existed as a Scientific Society and was the direct successor of the Orenburg scientific archival commission and the Orenburg department of the Russian geographical society. For the entire period of his scientific activity (1920-1932) The society was engaged in a comprehensive study of Kazakhstan and the Kazakh people. In the "Works» of the Society there are a number of works devoted to the study of geographical features of the regions of Kazakhstan, historical events of the second half of the XVIII-early XIX centuries. The "Works» of the Society for the study of the Kazakh region» made a huge contribution to the development of local history in Kazakhstan.

Keywords: archive business, library, society, department, bibliographic essay, chairman, academic commission.

\section{Д.Д.Есімханов}
${ }^{1}$ Қ.Жұбанов атындавы Ақтөбе өңірлік университеті, «Тарих» мамандывының 2 курс магистранты, Ақттөбе, Қазақстан,_E-mail: good_treiser.97@mail.ru ${ }^{2}$ т.в.к., Қ.Жұбанов атындавы Ақ̆төбе өңірлік университетінің доценті, Ақ̆төбе, Қазақсттан, E-mail:shibek_07@mail.ru

\section{«ҚАЗАҚ ЖЕРІН ЗЕРТТЕУ ҚОҒАМЫНЫН» ЕНБЕКТЕРІ ҚАЗАҚСТАН ТАРИХЫ МЕН ГЕОГРАФИЯСЫН ЗЕРТТЕУДІН ҚАЙНАР КӨЗІ РЕТІНДЕ}

\section{Анъдатпа}

Бұл мақ̆ала Қазақ өлкесін зерттеу қ̧огамының «Еңбектерін» зерттеуге арналzан. «Қазақ өлкесін зерттеу қогамы» вылыли құовам құқыгымен жұмыс істеді және Орынбор вылыми мұрагат комиссиясы мен Орыс Географиялық қогамының Орынбор бөлімінің тікелей мұрагері болды. «Қазақ өлкесін зерттеу құовамыл» өзінің вылылыи қъызметінің барлық кезеңъінде (1920-1932 жылдары) Қазақстан мен құазақ халқыын жан-жақты зерттеумен айналысты. Қогамның «Еңбектерінде» Қазақстан өңірлерінің географиялық ерекшеліктерін, ХVIII васырдың екінші жартысы мен ХІХ васырдың басындавы тарихи оқиваларды зерттеуге арналган бірқатар жұмыстар бар. «Қазақ өлкесін зерттеу құовамының» «Еңбектері» Қазақстандавы өлкетанудың дамуына үлкен үлес қоосты.

Кілт сөздер: мұрават ісі, кітапхана, қовам, бөлім, библиографиялық очерк, төрава, вылыми комиссия.

\section{Д.Д.Есимханов ${ }^{1}$, Ж.С.Бегимбаева}

${ }^{\prime}$ магистрант 2 курса спещиальности «История», Актюбинский региональный университет им.К.Жубанова, Актобе, Казахстан, E-mail: good_treiser.97@mail.ru ${ }^{2}$ к.и.н., доцент Актюбинского регионального университета им.К.Жубанова, Актобе, Казахстан, E-mail:shibek_07@mail.ru 


\title{
ТРУДЫ «ОБЩЕСТВА ИЗУЧЕНИЯ КАЗАХСКОГО КРАЯ» КАК ИСТОЧНИК ДЛЯ ИССЛЕДОВАНИЯ ИСТОРИИ И ГЕОГРАФИИ КАЗАХСТАНА
}

\begin{abstract}
Аннотачия
Это статья посвящена изучению «Трудов» Общества изучения Казахского края». «Общество изучения Казахского края» существовало на правах Ученого общества и являлось прямым преемником Оренбургской Ученой архивной комиссии и Оренбургского отдела Русского географического общества. За весь период своей научной деятельности (1920-1932 годы) Общество занималось всесторонним изучением Казахстана. В «Трудах» Общества имеется ряд работ посвященных изучению географических особенностей регионов Казахстана, историческим событиям второй половины XVIII - начало XIX веков. «Труды» Общества изучения Казахского края» внесли огромный вклад в развитие краеведения в Казахстане.
\end{abstract}

Ключевые слова: архивное дело, библиотека, общество, отделение, библиографический очерк, председатель, ученая комиссия.

\section{Introduction:}

The "Society for the Study of the Kazakh Region" existed as a Scientific Society and was the direct successor of the Orenburg Scientific Archival Commission and the Orenburg Department of the Russian Geographical Society. In the "Works" of the Society for the Study of Kazakhstan, the main emphasis is on the holistic study of the Kazakh people and Kazakhstan.

\section{Materials and methods:}

In the course of research work, methods of analysis and synthesis, historical method, historical-comparative, historical-spatial, historical-system method, historical-genetic methods of historical research were used. A particularly important role in the course of the study was assigned to the comparative method, which allowed the author to obtain scientific results on their reliability as a result of a comparative analysis of sources. The work also used the methods of source studies-specific analysis, interpretation and retrospection.

\section{Discussion:}

The "Proceedings" of the Society for the Study of Kazakhstan as a historical source contain valuable material on the history of Kazakhstan. The pages of the "Proceedings" of the Society for the Study of Kazakhstan reflect the issues of colonization of Kazakhstan, the course and results of various military expeditions directed by the tsarist government, and the protest movement of the Kazakh people against colonization.

\section{Research results:}

The scientific "Works" of the Society for the Study of Kazakhstan are of great value for geography, as they clearly set out the geographical descriptions of the territory of Kazakhstan. It also reflects the history of the development of education, the history of the origin and development of periodicals in the Orenburg Region, the issues of the formation and development of the scientific study of Kazakhstan, the economic development of the region, there are materials on historical geography, toponymy.

In 1919, at the headquarters of the Kazakh Military Commissariat (KMC), a historical and statistical department was founded with the «strictly scientific purpose of studying the long and recent past of the Kazakh territory and the Kyrgyz people in geographical, historical and ethnographic terms», which lasted less than six months. On April 10, in connection with the formation of civil government bodies, the historical and statistical department was transferred to the Department of Public Education of the Kazakh Revolutionary Committee (Kazrevkom) and became known as the Scientific commission [1, p.135].

In January 1920, through the efforts of A.P.Chuloshnikov, a scientific commission was formed at the Department of Public Education of the VRK, whose tasks included «drawing up instructions on archival affairs and saving ancient monuments, programs for collecting ethnographic materials» [2, p.42].

On October 15, 1920, the founding meeting of the «Society for the study of the Kazakh region» (OIKK) was held in Orenburg. The Society existed as a Scientific society and was a direct successor of the Orenburg scientific archive commission (OAC) and the Orenburg department of the Russian geographical society (RGS) until the resumption of their activities. A.P.Chuloshnikov was elected the first Chairman of the Society. The Society consisted of three sections: ethnographic, historical-archaeological and natural-geographical [3].On November 1, 1920, the «Society for the study of the Kazakh region» was registered. The scientific Department Kanakanak approved its Charter. According to the Charter, the «Society for the study of the Kazakh region» existed on the rights of a 
scientific society and was a direct receiver of the UAC and the Orenburg department of the RGS until the resumption of the activities of these societies [1, p.138].

The main task of the OIKC was «a comprehensive study of issues related to the Kyrgyz people» (including outside the Kazakh Republic), mainly in three areas, which corresponded to three departments (sections): historical-archaeological, ethnographic and natural-geographical. Section going is rarely due to busy service members OCC [4, p.100-101]. Over time, the historical and archaeological department was merged with the ethnographic department. According to the Charter of the Company, the Board is a voter for one year. A.P.Chuloshnikov was elected Chairman, and A.P.Gra, a former honorary member of the UAC, was elected Deputy Chairman. Secretary of the Board became I.M.Rastorguev, became head of the ethnographic Department - M.S.Petrov, natural geography - Vladimir Telezhnikov [1, p.140].

At the general annual meeting of the Company, held on December 23, 1923, on the basis of paragraph eighteen and nineteen of the Charter, the Board of Directors was elected for 1924, and the following were elected: Chairman of the Board K.K.Makovsky, Comrade of the Chairman M.I.Batalov, members of the Board: A.L.Melkov, V.V.Telezhnikov, A.P.Loshkarev. At the elections held on February 17, 1924, M.I.Rozhanets, Comrade of the Chairman P.A. Vorontsovsky and Secretary N.N.Banasevich were elected as the Chairman of the Department of natural science and geography. In the historical and ethnographic department, S.M.Petrov, Comrade of the Chairman Telzhan Shonanov and secretary E.A.Choglokov were elected chairman of the department at the elections held on February 5, 1924 [5, p.295]. The researcher P.Stepanov noted that the activity of the Society for twelve years can be divided into three periods not only by location, but by the nature of its activity into three periods: Orenburg (1920-1925), Kzyl-Ordinsky (1925-1929) and Almaty (since 1929) [1, p.140]. The department of history and ethnography in 1924 had seven meetings, at which reports were heard on the following topics: A.F.Pishchulin. Revolutionary movement of the 80 s of the XIX century in the Orenburg region, A.P.Chuloshnikov. New data in the science of the Peasant war under the leadership of Emelyan Pugachev and his reports of 1875. A.P.Chuloshnikov's report on the topic «On the question of the oldest Russian relations with the Kazakh Horde from the end of the XV to the beginning of the XVIII century» was heard at three meetings of the society.

Researcher A.F. Ryazanov prepared reports «Echoes of the Pugachev uprising» (Sultan Dosali, E.Pugachev in Berdakh) and «General outline of the Pugachev uprising and Kazakh Khanin». The first report was decided to be published in the «Proceedings» of the Society. The following reports are in a special collection dedicated to the memory of E.Pugachev, and the third report «take note» [5, p. 297 298]. Researcher A.F.Ryazanov in the essay «Sultan Dosali» considered the participation of the Kazakh people in the Peasant Uprising of 1773-1775 under the leadership of E. I. Pugachev. The author noted that only Sultan Dosali, the nephew of the Younger Zhuz Nurali Khan, «recognized the power of the new sovereign and gave E. Pugachev his son's amanats. "The latter's declared support for the «legitimate» sovereign (Pugachev), according to the author, was a tactical move for «dynastic and selfish purposes» [6, p.197].

In 1924, «Society for the study of the Kazakh land» finished the publication and circulated to all learned societies and institutions, to share with the public his edition of the I issuance V volume of «Proceedings» of the Society. In this issue was published the work of A.P. Chuloshnikov «Essays on the history of the Kazakh-Kyrgyz people in connection with the common historical destinies of other Turkic tribes» [5, p.299]. The author gave examples that characterize the economic activities of Kazakhs not only as exclusively nomadic pastoralists, but also familiar with settled life, agriculture. A.P. Chuloshnikov the conditionality of these activities is natural, geographical factors that are diverse on the vast territory of Kazakhstan. In the historiography of the problem of studying the ethnogenesis of the Kazakh people, several important applications were gradually crystallized. A. P. Chuloshnikov adhered to the idea that the nomadic way of life and cultural isolation of the Kazakhs is directly due to the type of their economy. Thus, the idea of the leading role of economy and lifestyle in the process of ethnogenesis was formulated [1, p. 141-142]. The second issue of this volume (issue 2 volume V), is already finished printing. It contains the following works: I.M.Krasheninnikov «Vegetation cover of the Kyrgyz Republic» (with a map and illustrations), S.E.Rozhanets - Kucherovskaya "Vegetation of the Semipalatinsk province" part 1, history of research, P.A.Vorontsovsky «To the biology of Acridodea» and "Small News", A.F.Ryazanov «Khiva raids into the Kyrgyz steppe in 1818», Gr. Serbarinov «Isatay Taimanov» (Essay of the people's movement in the Bukeev Horde in 1837-1838), A.L.Melkova «Materials of Kyrgyz ethnography», Report of the Society for the study of the Kirghiz region for 1923 [5, p. 299]. 
In 1925, the «Society for the study of the Kyrgyz territory «was transformed into the» Society for the study of Kazakhstan», it was separated from the scientific department of Kaznarkompros. The new Society, as a scientific institution, was engaged in a comprehensive study of Kazakhstan and neighboring regions in historical-archaeological, natural-geographical, and economic relations [7].

In the VI volume of «Proceedings of the Society for the study of Kazakhstan» for 1925, the Department of history and ethnography publishes the works of A.F.Ryazanov «Echoes of the Pugachev uprising in the Urals, the Kirghiz-Kaisat Small Horde and in the Volga region» and Professor A.N.Filippov «Moscow and Pugachev in July and August 1774» [8, p. 299]. Ryazanov A.F. in his work concerning the Younger zhuz, using archival materials of the Central archive of KazASSR, describes the movements of the «invisible» or «Kok-temir» (1925). Riazanov reports that the Orenburg governor Reinsdorp I. A. sends in the Younger zhuz their ambassadors marching as the captain he was born Adhamova and Raimkul Ibraeva. They, in turn, visited the reception of the Sultan of Dusali, and later in the village of the «invisible man» himself [8, p. 233-234]. Riazanov writes about the «invisibles»: «The «Holy invisibles, who points himself out as a boisterous bull, a kind-hearted father and the most holy light», as Sultan Dusali calls him, was none other than «the Kyrgyz wife Sapara, who was possessed by an unclean spirit from childhood. Fiction and superstition have created a ridiculous and strange legend around this woman. Sultan Dosali and his children used it for their own selfish purposes. They resorted to the witchcraft of the cleric Sapara to inspire the people, to excite wild fanaticism in them and to raise them for raids on the Russian borders. For them, it was very profitable, as they received prey-people and cattle. The dark, superstitious Kyrgyz masses simply believed in the invisible saint. Popular rumor about him spread to all the ulus of the Kyrgyz Horde. From all sides, the Kirghiz people flocked to the saint. His commands were obeyed as the will of a supreme being. «Sultan Dosali, being at enmity with the Khan of the Younger zhuz Nurali, uses the «invisible» for his own purposes to fight the Russian Empire [8, p. 235-236].The department of natural science and geography held six meetings in 1924, at which the following scientific reports were heard: M.I.Rozhanets «Soils of the Pavlodar district», K.K. Sakovsky «Results of the survey of animal husbandry in the Orenburg province», N.A.Mokeev «Climatic sketch of the Orenburg Mountains», M.I.Rozhanets «The role of V.V.Dokuchaev in soil science (to the 20th anniversary of his death)», I.P.Slovokhodov «Scientific merits of Kirchhoff (to the 100th anniversary of his death)», A.S.Bludorov «Natural laws of morality» [5, p. 297-298].

In 1925, in the VI volume of «Proceedings of the Society for the study of Kazakhstan», the Department of natural science and geography published the works of V.I.Baranov «The southern border of the chernozem steppes in the Kustanai province» and P.A.Vorontsovsky «Materials for the study of the fauna of the Odonata of the environs of Orenburg according to observations of 1922», as well as the work of N.A.Mokeev «A Brief climatic review of the Orenburg region for a long period (1886-1924)» [8, p.3]. Mokeev N.A. when starting to compile his essay of the Orenburg region, he had at his disposal mainly sources that do not give a complete description of the climate, in view of which he had to limit himself to the average monthly data. But since the latter in themselves do not give a clear picture, he took as a basis the method of identifying various abnormal deviations, the so-called climate stability. He was able to describe the atmospheric pressure, temperature, cloud cover, and humidity for the period 1886-1924 [8, p. $3-5]$.

Soon etomology Vorontsov P.A. will publish in the magazine «Soviet Kyrgyzstan» a number of articles, namely: 1) Local history and the Central museum of the KSSR, 2) Enemies of the field economy of the KSSR and the fight against them, 3) Medical insects Kirra, 4) Mechanical chemical methods of agricultural pest control, 5) Dependence of yields and locust reflection on the state of sunspots; 6) On the issue of studying «locusts» [5, p. 301].

In his work «Materials for the study of the fauna Odonata of the environs of Orenburg according to observations of 1922», Vorontsovsky P.A. describes his first excursion made on May 27 along the banks of the Myakutina Pit and lakes between the Pit and Lake Bukhara, where he caught 10 species of dragonflies. He gives descriptions of the length of the body parts of this insect, as well as what color they have [8, pp. 78-80]. In the third issue of «Works» in honor of the 50th anniversary of the birth of Akhmet Baitursynov, the works of Ildes Omarov «The scientific activity of A.B.Baitursynov» and the bibliographic essay of Mirzhakip Dulatov «Akhmet Baitursynovich Baitursynov» were published [1, p.149]. The linguist Baitursynov A.B. wrote a number of textbooks and manuals on Kazakh literature, literature and cultural history. The scientific work has a creative character and is a contribution of great value to the treasury of the Kazakh people. Akhmet Baitursynov also worked in the Scientific Council of the People's Commissariat of education [5, p. 301]. In the "Proceedings of the Society for the study of Kazakhstan» for 1922, an essay by Mirzhakip Dulatov was published, in which he describes 
the life of Akhmet Baitursynov: «Akhmet Baitursynovich with great difficulties and hardships after completing the course of the Turgay school, in 1891 he plans to enter Orenburg to continue his education». The pedagogical activity of Akhmet Baitursynovich begins in 1895. In the period from 1895 to 1909, he taught in aul, volost and two-class schools in Aktobe, Kustanai and Karkaraly counties. The author noted that «Akhmet Baitursynov is a publicist and creator of the school of Kyrgyz (Kazakh) literary literature. As a publicist, Akhmet Baitursynov had almost no money, in early 1913 he founded the first Kazakh newspaper in the full sense of the word «Kazakh» in Orenburg, on the pages of which he boldly put forward the needs of the Kazakh people.The newspaper «Kazakh» in the history of the young Kazakh press took the first place of honor. After the February Revolution, Akhmet Baitursynov was drawn into the maelstrom of social and political life. He was elected as a member of the All - Russian Constituent Assembly-from the Turgay region on the list of the nationalist party «Alash». Akhmet Baitursynov worked as a teacher of the Kazakh Institute and chairman of the Scientific and Literary Commission under the People's Commissariat of Education and Honorary Chairman of the Society for the study of the Kazakh Region. As a result of the scientific and pedagogical works of Akhmet Baitursynov, we have the Kazakh alphabet, phonetics, syntax and etymology of the Kazakh language, the theory of literature and the history of culture [9, p. 24-25]. In the second issue of the VII volume of «Proceedings of the Society for the study of Kazakhstan», which was published in 1926 in the city of Kyzyl-Orda, the Department of history and ethnography publishes the work of A.F.Ryazanov «Forty years of struggle for the national independence of the Kazakh people (1797-1838)». In his works, he describes in detail the political events that took place in the Younger zhuz [10, p.3]. He also tells about the abolition of the khan's power in the Younger zhuz: «After the death of Khan Abulkhair, who had accepted citizenship, a candidate who was pleasing to the government was always held for the khan's position, and the Kyrgyz congress, under pressure from the Russian military force or through bribing influential people in the Horde, agreed to the election of the candidate designated by the government. It was impossible to establish peace and order in the horde by haphazard military expeditions. It was necessary to abandon the border management system and create government authorities within the horde itself, which would allow covering the Kyrgyz masses and carrying out government activities in their thickness» [10, p. 152-152].

In 1929, the X volume «Labor Society for the study of Kazakhstan» was published in Almaty. In this Department of natural science and geography published work: Tomaszewski I. "Natural-historical conditions Kirghiz-kaisak environment», Pallone of L.I. «Lake Charkhal in the Ural provinces», Naumov S.P. and Spangenberg E.P. «Results of field biological surveys sandy the squirrel in the Northern KyzylKum and Aral Kyzyl-Kum», Ivanov P.V. «Jute 1927\1928 G. in Syrdarya province», Alexander P., «Tuberculosis of the Cossacks», but in the same article Larina, I. V., «The memory of S.S.Neustruev» [11, p. 2].Researcher Larin I.V. in his article «In Memory of S.S.Neustruev» describes a brief biography, and also reveals the significance of S.S.Neustruev's works for Kazakhstan. So Larin I. V. wrote: «In the works of Sergei Semyonovich Neustruev», not only the soils were described, but also the general geographical characteristics and division of counties into natural areas were published. He also noted that «there was one trait in Sergei Semyonovich, he never showed his students his constant scientific superiority» $[11$, p. $7-8]$.

In the «Works» of the Society for the study of Kazakhstan, the main emphasis is on the holistic study of the Kazakh people and Kazakhstan. The scientific «Works» of the Society for the study of Kazakhstan are of great value for geography, as they clearly set out the geographical descriptions of the territory of Kazakhstan. Employees of the Society published a number of interesting works related to the political situation in the Younger zhuz, which gave a complete picture of historical reality, the period of the Emelyan Pugachev uprising and the "invisible" movement. Representatives of the artistic intelligentsia, who were employees of the «Society for the study of Kazakhstan», were the authors and publishers of the first books in the Kazakh language. For all the years of its scientific activity, the «Society for the study of Kazakhstan» has become one of the centers for the dissemination of culture.

\section{Conclusion:}

For the entire period of his scientific activity (1920-1932) The Society was engaged in a comprehensive study of Kazakhstan and the Kazakh people. In the "Works" of the Society there are a number of works devoted to the study of geographical features of the regions of Kazakhstan, historical events of the second half of the XVIII - early XIX century. "The works of the" Society for the Study of the Kazakh Region " made a huge contribution to the development of local history in Kazakhstan. 
1.Begimbayeva Zh.S. Scientific Societies for the study of Kazakhstan in the second half of the XIX-30s of the XX centuries, Aktobe: "Zhubanov University», 2019. - 384p.

2.Tugai T.I. Orenburg regional studies in the preservation of historical and cultural monuments (1917-1930), Orenburg: IPK «Universitet» LLC, 2016. 132p.

3.Electronic resource access mode: http://1743.ru/news/41116-v-oblastnom-centre-otkryliobshchestvo-dlya-izucheniya-kirgizskogo-kraya

4.Proceedings of the Society for the study of the Kyrgyz region, Orenburg, 1921. -110p.

5.Report of the Society for the study of the Kyrgyz region for 1924. Proceedings of the Society for the study of Kazakhstan (Kirghiz region), Orenburg 1925. - 295p.

6.Safronov D.A. Essays on historiography of Orenburg history, Orenburg: Publishing House «Orenburg Province», 2005. - 296p.

7.Electronic resource access mode: https://myaktobe.kz/archives/39606

8.Proceedings of the Society for the study of Kazakhstan (Kyrgyz region) Volume VI, Orenburg, 1925. - 313p.

9.Proceedings of the Society for the study of the Kyrgyz region. Issue III, Orenburg, 1922. $195 p$.

10.Proceedings of the Society for the study of Kazakhstan (Kyrgyz region) Volume VII, KzylOrda, 1926. - 294p.

11.Proceedings of the Society for the study of Kazakhstan (Kyrgyz region) Volume X, Alma-Ata, 1929. - $215 p$.

\section{Список литературы:}

1. Бегимбаева Ж. С. Научные общества по изучению Казахстана второй половины XIX-30-х годов ХХ веков, Актобе: «Университет имени Жубанова», 2019. - 384 c.

2. Тугай Т. И. Оренбургское краеведение в сохранении памятников истории и культуры (19171930 гг.). Оренбург: ООО ИПК «Университет», 2016. - 132 c.

3. Режсим доступа к электронныли ресурсам: http://1743.ru/news/41116-v-oblastnom-centre-otkryliobshchestvo-dlya-izucheniya-kirgizskogo-kraya

4. Труды Общества изучения Киргизского края, Оренбург, 1921. - 110 с.

5. Отчет Общества по изучению Киргизской области за 1924 год. Труды Общества изучения Казахстана (Киргизская область), Оренбург, 1925. - 295 с.

6. Сафронов Д. А. Очерки по историографии истории Оренбурга, Оренбург: Изд-во «Оренбургская губерния», 2005. - 296 с.

7. Режим доступа к электронным ресурсам: https://myaktobe.kz/archives/39606

8. Труды Общества изучения Казахстана (Киргизской области) Том VI, Оренбург, 1925. - 313 c.

9. Труды Общества по изучению Кыргызского региона. Выпуск III, Оренбург, 1922. - 195 с.

10.Труды Общества изучения Казахстана (Кыргызская область) Том VII, Кзыл-Орда, 1926. - 294

$c$.

11. Труды Общества изучения Казахстана (Кыргызская область) Том Х. - Алма-Ата, 1929. - 215 c. 